ISSN 1678-3921

Journal homepage: www.embrapa.br/pab

For manuscript submission and journal contents, access: www.scielo.br/pab

\section{Planting density and yield of sweet pepper grown in an organic system}

\begin{abstract}
The objective of this work was to evaluate the yield and fruit quality of sweet pepper (Capsicum annuum) genotypes grown at various planting densities, in an organic production system under protected cultivation. The experiment was carried out in duplicate, to compare the yield and fruit quality of the 'TE 300', 'Mallorca', and 'Timor' sweet pepper genotypes, at the densities of $2,4,6$, and 8 plants $\mathrm{m}^{-2}$. A randomized complete block design was used, with three replicates, in split plots. Mean fruit size and mass, yield per plant, and total yield were measured. Dunnett's test was used to compare means between the standard density of 2 plants $\mathrm{m}^{-2}$ and the other densities. Scott-Knott's test was used to compare the densities within each genotype. The increase of planting density in the organic production system provided a yield similar to that of the conventional system. A greater density increases yield and reduces the production cycle, without impairing the fruit size or quality of the 'TE 300 ' and 'Timor' genotypes. The densities of 8 plants $\mathrm{m}^{-2}$ for 'TE 300' and 'Timor', and of 6 plants $\mathrm{m}^{-2}$ for 'Mallorca' show the highest total yield per hectare.
\end{abstract}

Index terms: Capsicum annuиm, fruit quality, protected cultivation.

\section{Densidade de plantio e produtividade de pimentão em sistema orgânico de produção}

Resumo - O objetivo deste trabalho foi avaliar a produção e a qualidade dos frutos de genótipos de pimentão (Capsicum annuиm) submetidos a várias densidades de plantio, em sistema orgânico de produção sob cultivo protegido. $\mathrm{O}$ experimento foi realizado em duplicata, para comparar o rendimento e a qualidade dos frutos dos genótipos de pimentão 'TE 300', 'Mallorca' e 'Timor' quanto às densidades de plantio de 2, 4, 6 e 8 plantas $\mathrm{m}^{-2}$. Utilizou-se o delineamento de blocos ao acaso, com três repetições, em parcelas subdivididas. O tamanho e a massa médios dos frutos, a produção por planta e a produção total foram determinados. O teste de Dunnett foi usado para contrastar médias entre a densidade padrão de 2 plantas $\mathrm{m}^{-2}$ e as demais densidades. O teste de Scott-Knott foi usado para comparar as densidades dentro dos genótipos. O aumento da densidade de plantio no sistema orgânico proporcionou produção similar à do sistema convencional. A maior densidade aumenta a produção e encurta o ciclo de produção, sem prejudicar o tamanho ou a qualidade dos frutos dos genótipos 'TE 300' e 'Timor'. As densidades de 8 plantas $\mathrm{m}^{-2}$, para 'TE 300' e 'Timor', e a de 6 plantas $\mathrm{m}^{-2}$, para 'Mallorca', apresentam maior produção total por hectare.

Termos para indexação: Capsicum annuum, qualidade de fruto, cultivo protegido. 


\section{Introduction}

Sweet pepper (Capsicum annuum L.) is one of the most produced vegetables worldwide, among the 10 most cultivated ones (Shahbandeh, 2021). In Brazil, sweet pepper has a prominent position, ranking third among the most cultivated Solanaceae, only behind tomato (Solanum lycopersicum) and potato (Solanum tuberosum) (Santos et al., 2020).

One of the main attractions for sweet pepper consumption is its wide range of colors, shapes, and flavors, in addition to the presence of several vitamins such as vitamins A, C, and folate (Kantar et al., 2016) and essential nutrients, such as phosphorus, calcium, and potassium (Guilherme et al., 2020). Peppers from organic production systems have higher concentrations of these nutrients, in comparison with those produced in conventional system (Worthington, 2001; Hallmann \& Rembiałkowska, 2012; Guilherme et al., 2020).

Although the organic agriculture production data show that, on average, the reduction of the sweet pepper yield is $19.2 \%$, in comparison with the conventional agriculture (Ponisio et al., 2015), some techniques are adopted for the cultivation of this crop, to minimize costs and production losses caused by other factors, such genotype adaptation (Ribes-Moya et al., 2018; Boyhan et al., 2020; Scalzo et al., 2020), balanced organic fertilization, soil salinization, mycorrhizal inoculation (Zayed et al., 2013), and ripening stage (Ribes-Moya et al., 2018).

A possible way to reduce the production costs and deliver a better quality organic product to the population is by increasing the plant density at planting, which would allow of more fruit to be grown in a smaller physical space. There are few studies on the density management for the production of sweet pepper (Khasmakhi-Sabet et al., 2009; Islam et al., 2011; Abu \& Odo, 2017). Decreasing planting density of sweet pepper cultivation in conventional system increased plant vigor, as well as number of branches, leaves and fruit per plant (Islam et al., 2011). The increase in plant density considerably affects crop production, since higher-density crops may produce more fruit, but these may be smaller, so there should be a balance between the number of plants per square meter, the number of fruit per plant, and the duration of the crop cycle that maintains yield. Conversely, in less dense crops, fewer fruit of larger size may be produced, maintaining quality, in comparison with normally grown crops, which means that only the aesthetic traits of the product will be affected, something that should be taken into account to decide which will be the appropriate market niche (Silva, 2008; Abu \& Odo, 2017).

Although there are sweet pepper genotypes better suited for the organic system (Boyhan et al., 2020; Scalzo et al., 2020), and some genotypes cultivated in conventional system in Brazil have a great yield response, there is no information on the productivity of these genotypes in an organic system.

The objective of this work was to evaluate the yield and quality of sweet pepper fruit of genotypes subjected to planting densities, in an organic production system under protected cultivation.

\section{Materials and methods}

The experiments were carried out between February and September 2018, in a greenhouse covered with $92 \%$ of $3 \mathrm{~m}$ high transparency diffuser plastic, opened at four lateral sides, at Instituto Federal de Educação, Ciência e Tecnologia do Sul de Minas Gerais, Campus Inconfidentes, in the municipality of Inconfidentes $\left(22^{\circ} 19^{\prime} 00^{\prime \prime} \mathrm{S}, 46^{\circ} 19^{\prime} 40^{\prime \prime} \mathrm{W}\right.$, at $869 \mathrm{~m}$ altitude), in the state of Minas Gerais, Brazil. The temperature ranged from 2.8 to $32.9^{\circ} \mathrm{C}$, averaging $18.7^{\circ} \mathrm{C}$, while the environment relative humidity was $78 \%$.

The experiment was conducted twice, and each one was set up in a randomized complete block design, with three replicates, in a split-plot design (genotype within planting density), in subplots of $2 \mathrm{~m}^{2}$ each. The treatments consisted of three green sweet pepper genotypes, 'TE 300' (popularly known as Maestro), 'Mallorca', and 'Timor', each one subjected to four planting densities, with a standard density of 2 plants $\mathrm{m}^{-2}$, and testing densities of 4,6 , and 8 plants $\mathrm{m}^{-2}$.

Manual sowing was performed in polypropylene trays filled with organomineral substrate Carolina Soil type (peat, vermiculite, and limestone). When plants reached six fully expanded leaves, the seedlings were transplanted to beds previously prepared with added cattle manure and poultry litter at 5 and $2 \mathrm{~L} \mathrm{~m}^{-2}$, respectively.

Irrigation was performed every 2 days, using the drip system, and the phytosanitary control was performed by prescheduled preventive spraying. Cow urine $(1.26 \% \mathrm{~N}, 0.01 \% \mathrm{P}, 0.27 \% \mathrm{~K}, 0.03 \% \mathrm{Mg}, 0.01 \%$ $\mathrm{B}$, and traces of other micronutrients) (Oliveira et al., 2010) was used weekly by foliar spray at $50 \mathrm{~mL}$ 
concentration per $20 \mathrm{~L}$ water., in addition to Bokashi organic substrate (PlantaeFert Adubos Orgânicos, São Paulo, SP, Brazil) at $150 \mathrm{~g}$ concentration per $20 \mathrm{~L}$ water, every two weeks, in soil application to provide nutrients and organic matter, $0.75 \mathrm{~g}$ sodium molybdate per $20 \mathrm{~L}$ water to repel ants (weekly), and $50 \mathrm{~mL}$ neem oil (DalNeem, Itajaí, SC, Brazil) per $20 \mathrm{~L}$ water for insect control and antimicrobial action (weekly).

The weekly harvest began at 90 days after sowing and lasted for 8 weeks, ending when increased competition between plants, at the highest spacing, and increased pathogen pressure were observed. The diameter and length (both in $\mathrm{cm}$ ) of fruit, the mean fruit mass (g), yield (g) per plant, the yield fruits per plant, and the yield $(\mathrm{Mg})$ per hectare were evaluated.

The average data of the two experiments were subjected to the analysis of variance, and the mean comparisons were performed for the higher-density group with the standard density ( 2 plants $\mathrm{m}^{-2}$ ) group by Dunnett's test, at 5\% probability, and for the densities within each genotype by Scott-Knott's test (Scott \& Knott, 1974), at 5\% probability. All statistical analyses were performed using the Genes software (Cruz, 2013).

\section{Results and Discussion}

A significant difference was observed for all evaluated traits in each genotype, except for fruit length, in all genotypes, and yield per plant, in 'Mallorca' (Table 1). The coefficients of variation were lower at the subplot level than at the plot level, which was expected because in the plot, despite the same planting density, there was the presence of genetic variation between the three genotypes used, in addition to the expected environmental variation (Table 1). Nevertheless, the values of the coefficients of variation were classified as moderate at field level, which indicates a good experimental accuracy (Silva et al., 2011).

Fruit size is a very important characteristic in the commercial classification, since in most cases the fruit is given a pre-classification, by which fruit diameter and length are key parts of the fruit market value (Lima et al., 2018). In the case of organic cultivation, it is ideal for fruit size to be kept at values comparable to those of conventional cultivation.

Table 1. Mean values of fruit traits of sweet pepper (Capsicum annuum L.) genotypes subjected to increasing planting densities in an organic production system ${ }^{(1)}$.

\begin{tabular}{|c|c|c|c|c|c|c|c|}
\hline \multirow[t]{2}{*}{ Genotype } & \multirow[t]{2}{*}{ Plants $\mathrm{m}^{-2}$} & \multicolumn{6}{|c|}{ Trait $^{(2)}$} \\
\hline & & $\begin{array}{l}\text { Fruit diameter } \\
\qquad(\mathrm{cm})\end{array}$ & $\begin{array}{l}\text { Fruit length } \\
\qquad(\mathrm{cm})\end{array}$ & $\begin{array}{l}\text { Mean mass } \\
(\mathrm{g})\end{array}$ & $\begin{array}{l}\text { Yield per plant } \\
\text { (g) }\end{array}$ & $\begin{array}{l}\text { Yield per plant } \\
\text { (fruit) }\end{array}$ & $\begin{array}{c}\text { Total yield } \\
\left(\mathrm{Mg} \mathrm{ha}^{-1}\right)\end{array}$ \\
\hline \multirow{3}{*}{ TE 300} & 4 & $6.87 \mathrm{c}^{\mathrm{ns}}$ & $7.50 \mathrm{a}^{\mathrm{ns}}$ & $74.34 b^{*}$ & $468.22 \mathrm{a}^{\mathrm{ns}}$ & $6.29 \mathrm{a}^{\mathrm{ns}}$ & $18.72 b^{*}$ \\
\hline & 6 & $11.11 \mathrm{a}^{*}$ & $7.50 \mathrm{a}^{\mathrm{ns}}$ & $60.97 \mathrm{c}^{*}$ & $318.19 \mathrm{c}^{\mathrm{ns}}$ & $5.55 \mathrm{a}^{\mathrm{ns}}$ & $19.09 b^{*}$ \\
\hline & 8 & $9.38 \mathrm{~b}^{*}$ & $8.00 \mathrm{a}^{\text {ns }}$ & $88.52 \mathrm{a}^{*}$ & $387.22 \mathrm{~b}^{\mathrm{ns}}$ & $4.54 b^{\text {ns }}$ & $30.97 a^{*}$ \\
\hline \multirow{3}{*}{ Mallorca } & 4 & $7.79 b^{\text {ns }}$ & $8.59 a^{*}$ & $111.57 \mathrm{a}^{*}$ & $349.01 b^{\mathrm{ns}}$ & $3.25 \mathrm{a}^{\mathrm{ns}}$ & $13.96 c^{*}$ \\
\hline & 6 & $9.57 \mathrm{a}^{*}$ & $10.11 \mathrm{a}^{*}$ & $97.16 c^{*}$ & $419.35 \mathrm{a}^{\mathrm{ns}}$ & $4.40 \mathrm{a}^{\mathrm{ns}}$ & $25.16 a^{*}$ \\
\hline & 8 & $8.55 \mathrm{a}^{\mathrm{ns}}$ & $8.74 \mathrm{a}^{*}$ & $99.62 b^{*}$ & $244.72 c^{*}$ & $2.79 \mathrm{a}^{\mathrm{ns}}$ & $19.57 b^{*}$ \\
\hline \multirow{3}{*}{ Timor } & 4 & $9.52 b^{\text {ns }}$ & $8.68 a^{\text {ns }}$ & $86.32 b^{*}$ & $395.20 \mathrm{~b}^{*}$ & $4.62 b^{*}$ & $15.80 b^{*}$ \\
\hline & 6 & $8.93 b^{\text {ns }}$ & $7.55 \mathrm{a}^{\mathrm{ns}}$ & $81.76 \mathrm{c} *$ & $479.62 \mathrm{a}^{\mathrm{ns}}$ & $6.11 \mathrm{a}^{\text {ns }}$ & $28.77 \mathrm{a}^{*}$ \\
\hline & 8 & $10.80 a^{*}$ & $9.29 \mathrm{a}^{\mathrm{ns}}$ & $87.71 \mathrm{a}^{*}$ & $355.90 c^{*}$ & $4.06 b^{*}$ & $28.47 \mathrm{a}^{*}$ \\
\hline \multicolumn{8}{|l|}{ Standard } \\
\hline TE 300 & 2 & 5.96 & 8.19 & 65.92 & 325.93 & 5.62 & 10.95 \\
\hline Mallorca & 2 & 6.43 & 19.17 & 90.61 & 353.12 & 4.25 & 7.06 \\
\hline Timor & 2 & 7.42 & 9.06 & 72.53 & 578.75 & 8.37 & 11.57 \\
\hline CV $1(\%)^{(3)}$ & & 26.4 & 30.58 & 30.91 & 28.5 & 39.02 & 28.36 \\
\hline CV $2(\%)^{(4)}$ & & 16.83 & 25.83 & 16.88 & 24.94 & 34.6 & 27.29 \\
\hline
\end{tabular}

${ }^{(1)}$ Means followed by the equal letters, within each genotype, do not differ, by Scott-Knott's test, at $5 \%$ probability. ${ }^{(2)}$ The values are the average of three replicates of two field experiments. ${ }^{(3)}$ Coefficient of variation at the plot level. ${ }^{(4)}$ Coefficient of variation at the subplot level. *Significantly different from the standard spacing of 2 plants $\mathrm{m}^{-2}$ by Dunnett's test, at $5 \%$ probability. ${ }^{\mathrm{n}}$ Nonsignificant. 
According to Dunnett's test (at 5\% probability), the highest diameter occurred at the density of 6 plants $\mathrm{m}^{-2}$ for 'TE 300' and 'Mallorca' genotypes, and at the density of 8 plants $\mathrm{m}^{-2}$ for 'Mallorca' and 'Timor' (Table 1). These results suggest that even with the increased planting density, until 6 or 8 plants $\mathrm{m}^{-2}$, depending on the genotype, there was an increase of the fruit diameter. Fruit length changed with density only for 'Mallorca' genotype, when comparing superior densities with the standard at 2 plants $\mathrm{m}^{-2}$. The increase of planting density caused a reduction of fruit length, starting at 4 plants $\mathrm{m}^{-2}$, which then remained stable until the density of 8 plants per $\mathrm{m}^{-2}$. Pimenta et al. (2016) worked with organic sweet pepper cultivation, and obtained values similar to those of the present study, with $7.01 \mathrm{~cm}$ mean fruit diameter of and $10.36 \mathrm{~cm}$ length. However, these authors used $1.0 \times 0.6 \mathrm{~m}$ spacing, corresponding to 1.66 plants $\mathrm{m}^{-2}$, which is lower than the lowest density in the present study. In the present work, the increase of plant density did not affect negatively the fruit quality for length, except for fruit of the 'Mallorca' genotype, indicating an inadequate density for this genotype when larger fruit are desirable (Table 1 and Figure 1).

In addition to diameter and length, an important characteristic in the classification of sweet pepper fruit, which should be preserved in organic cultivation, is the fruit mass. For the three genotypes evaluated in the present study, planting density resulted in significant differences for fruit mass, in the comparison of the standard spacing of 2 plants $\mathrm{m}^{-2}$ (Table 1). For the
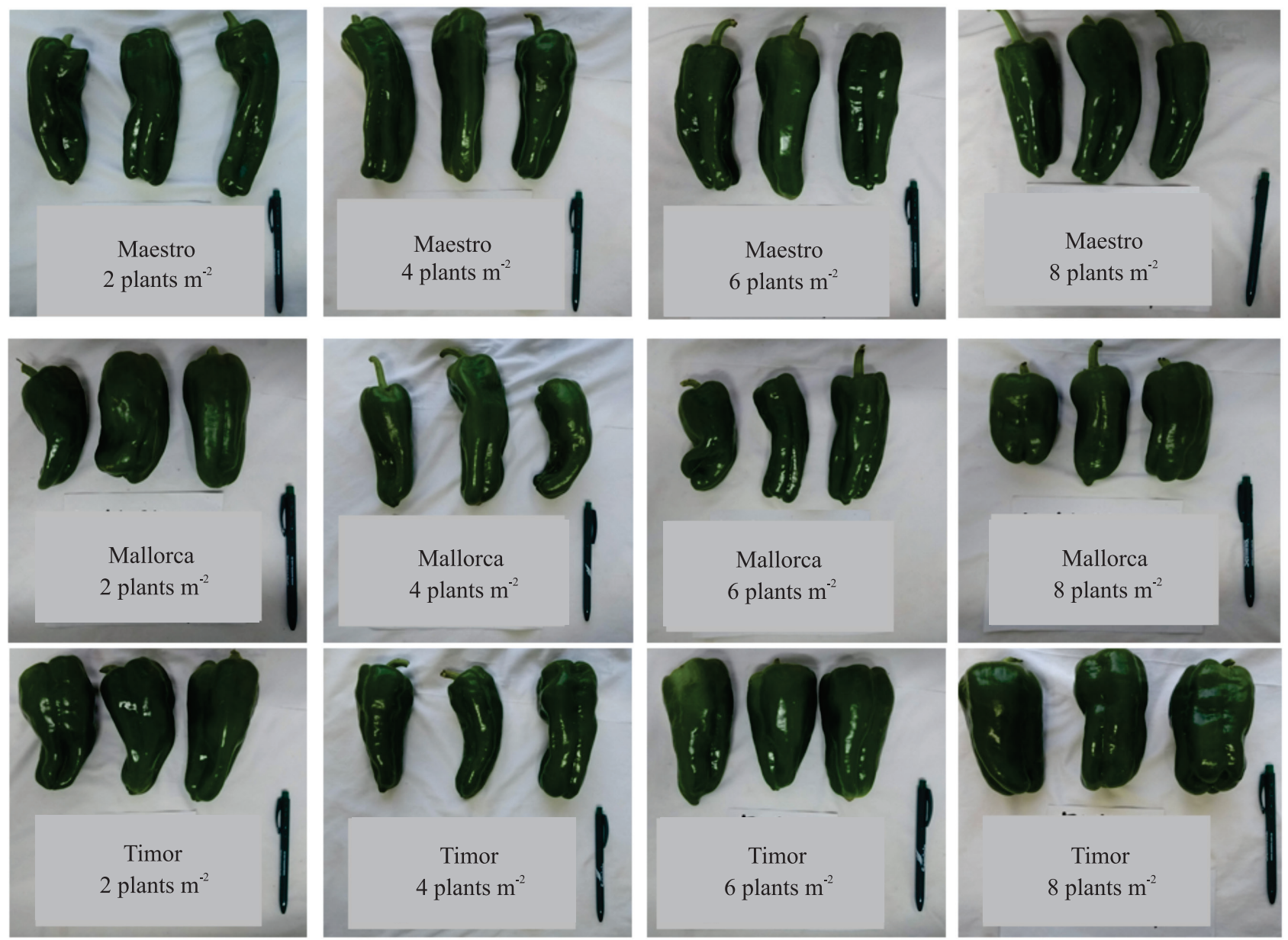

Figure 1. Fruit of green pepper (Capsicum annuum L.) genotypes 'TE 300', 'Mallorca', and 'Timor', produced at increasing planting densities in an organic production system. 
'TE 300' and 'Timor' genotypes, the density of 8 plants $\mathrm{m}^{-2}$ resulted in the highest mean fruit mass. For 'Mallorca', although planting density resulted in denser fruit, densities greater than 4 plants $\mathrm{m}^{-2}$ were not advantageous for this trait. These data suggest that this genotype should be exploited at a maximum of 40,000 plants ha $^{-1}$, to obtain satisfactory fruit quality.

The ability of 'TE 300' and 'Timor' to produce fruit of greater mass at higher densities suggests that the good performance of these genotypes was due to good genetic conditioning of the plants for growth in different situations. Therefore, these genotypes are more indicated for high-density cultivation in organic systems without loss of quality (Paulus et al., 2015). The reduction of fruit mass at higher densities of 'Mallorca' suggests lower development rates, which can be explained by its genetic constitution (Hachmann et al., 2017). Many plants cultivated close to each other increases their competition, hindering the fruit development. However, higher plant densities should be considered, for the improvement of fruit mass of 'TE 300' and 'Timor' genotypes.

When increasing the number of plants per unit area in search of higher yields, it is expected that the amount of sweet pepper produced - both in number of fruit and in fruit mass $(\mathrm{kg})$ per plant - will be reduced, as a function of the increased competition for water, light, and nutrients. When planted at a higher density, the greater number of neighboring plants can mitigate the incidence of sunlight, water and nutrients, so that the plant exhibits a maximum development, without affecting the quantity or quality of the fruit. In this sense, even with the increase of plants per area, the number and weight of fruit can be higher (KhasmakhiSabet et al., 2009; Islam et al., 2011).

In the present study, which aimed to test the ability of three sweet pepper genotypes to remain productive under a higher number of plants per square meter, significant reductions of yield (g) per plant were observed when the planting density was increased, in comparison with the standard density for 'Mallorca' and 'Timor' genotypes (Table 1). For 'TE 300', planting density did not cause any change in the yield per plant, regardless of whether the planting density was 2, 4, 6 , or 8 plants $\mathrm{m}^{-2}$. This greater ability of 'TE 300' to maintain an acceptable yield, even under conditions of greater competition, suggests a greater adaptability to high-density cultivation systems, in organic production systems. Regarding organic cultivation, the financial return under this management system may be even higher, especially in large commercial centers.

The three genotypes at all densities showed a significant increase of total yield, in compared with the standard density of 2 plants $\mathrm{m}^{-2}$ (Table 1). In addition, there was an increase of the yields of 'TE 300' and 'Timor' genotypes, which showed the highest yield at the highest density corresponding to an increase of $182.8 \%$, in comparison with the standard spacing of 2 plants $\mathrm{m}^{-2}$. 'Mallorca' showed the optimal yield at 6 plants $\mathrm{m}^{-2}$, with average total yields greater than 25 $\mathrm{Mg} \mathrm{ha} \mathrm{a}^{-1}$. In comparison with the standard cultivation density, the percentage gain in yield was $256.3 \%$ for 'Mallorca'.

The yield values of the present study, under the conventional planting density of 2 plants $\mathrm{m}^{-2}$, are below those obtained by Oliveira et al. (2015) and Guilherme et al. (2020). These authors obtained yields greater than $30 \mathrm{Mg} \mathrm{ha}^{-1}$, but they used a conventional system, in open-field cultivation, using soluble fertilizers and chemical pesticides. High yields in that cultivation system can be obtained even under low plant densities, since sweet pepper plants can be harvested for more than four consecutive months (Charlo et al., 2011). In the present study, when the planting density increased, the yield obtained under organic cultivation conditions was similar to those described in the literature, and in a much shorter time period of less than two months of harvesting. Furthermore, if the genotype used was adapted, the increase of planting density would not result in the quality decrease of the fruit produced (Figure 1).

Thus, the results of the present study suggest that 'TE 300' and 'Timor' genotypes may be indicated for organic cultivation at high planting density, without compromising the quality of sweet pepper fruit. They showed yields comparable to those of the conventional system, in a shorter cycle.

\section{Conclusions}

1. The increase of sweet pepper (Capsicum annuum) planting density, in the organic production system, provides yields similar to those of the conventional system, in a shorter time period of less than two months of harvesting. 
2. 'TE 300' and 'Timor' sweet pepper genotypes can be indicated for high-density cultivation at 8 plants $\mathrm{m}^{-2}$ without loss of fruit quality.

3. The highest total yield can be obtained in 'TE 300 ' and 'Timor' genotypes, at 8 plants $\mathrm{m}^{-2}$, and in 'Mallorca', at 6 plants $\mathrm{m}^{-2}$.

\section{Acknowledgments}

To Núcleo Institucional de Pesquisa e Extensão do Instituto Federal de Educação, Ciência e Tecnologia do Sul de Minas Gerais (IFSULDEMINAS), Campus Inconfidentes, for funding and granting a scholarship to the second author (grant number 37722770); to employees of the Horticulture Sector of IFSULDEMINAS and to the study group on vegetable breeding.

\section{References}

ABU, N.E.; ODO, C.V. The effect of plant density on growth and yield of 'NsukkaYellow' aromatic pepper (Capsicum annuum L.). African Journal of Agricultural Research, v.12, p.1269-1277, 2017. DOI: https://doi.org/10.5897/ajar2016.11923.

BOYHAN, G.E.; MCGREGOR, C.; O'CONNELL, S.; BIANG, J.; BERLE, D. A comparison of 13 sweet pepper varieties under an organic farming system. HortTechnology, v.30, p.135-143, 2020. DOI: https://doi.org/10.21273/HORTTECH04455-19.

CHARLO, H.C. de O.; OLIVEIRA, S.F. de; CASTOLDI, R.; VARGAS, P.F.; BRAZ, L.T.; BARBOSA, J.C. Growth analysis of sweet pepper cultivated in coconut fiber in a greenhouse. Horticultura Brasileira, v.29, p.316-323, 2011. DOI: https://doi.org/10.1590/s0102-05362011000300010.

CRUZ, C.D. Genes: a software package for analysis in experimental statistics and quantitative genetics. Acta Scientiarum. Agronomy, v.35, p.271-276, 2013. DOI: https://doi.org/10.4025/actasciagron.v35i3.21251.

GUILHERME, R.; REBOREDO, F.; GUERRA, M.; RESSURREIÇÃO, S.; ALVARENGA, N. Elemental composition and some nutritional parameters of sweet pepper from organic and conventional agriculture. Plants, v.9, 863, 2020. DOI: https://doi.org/10.3390/plants9070863.

HACHMANN, T.L.; DALASTRA, G.M.; ECHER, M. de M.; LOZANO, C.S.; REZENDE, R. Características produtivas de duas cultivares de pimentão em substratos alternativos. Cultura Agronômica, v.26, p.502-513, 2017. DOI: https://doi.org/10.32929/2446-8355.2017v26n4p502-513.

HALLMANN, E.; REMBIAŁKOWSKA, E. Characterisation of antioxidant compounds in sweet bell pepper (Capsicum annuum L.) under organic and conventional growing systems. Journal of the Science of Food and Agriculture, v.92, p.2409-2415, 2012. DOI: https://doi.org/10.1002/jsfa.5624.
ISLAM, M.; SAHA, S.; AKAND, H.; RAHIM, A. Effect of spacing on the growth and yield of sweet pepper (Capsicum annuum L.). Journal of Central European Agriculture, v.12, p.328-335, 2011. DOI: https://doi.org/10.5513/JCEA01/12.2.917.

KANTAR, M.B.; ANDERSON, J.E.; LUCHT, S.A.; MERCER, K.; BERNAU, V.; CASE, K.A.; LE, N.C.; FREDERIKSEN, M.K.; DEKEYSER, H.C.; WONG, Z.-Z.; HASTINGS, J.C.; BAUMLER, D.J. Vitamin variation in Capsicum spp. Provides opportunities to improve nutritional value of human diets. PLoS ONE, v.11, e0161464, 2016. DOI: https://doi.org/10.1371/journal. pone. 0161464 .

KHASMAKHI-SABET, A.; SEDAGHATHOOR, S.; MOHAMMADY, J.; OLFATI, J.A. Effect of plant density on bell pepper yield and quality. International Journal of Vegetable Science, v.15, p.264-271, 2009. DOI: https://doi.org/10.1080/19315260902830793.

LIMA, J. de M.; MOREIRA, F.S.; SOUSA, J.P. de; BARBOSA, F.M.; GOMES, A.C.; DORNELAS, C.S.M.; BARBOSA, A.R.; LACERDA, A.V. de. Caracterização de frutos de espécies de pimentas produzidas na região do Cariri paraibano. Revista Brasileira de Gestão Ambiental e Sustentabilidade, v.5, p.239247, 2018. DOI: https://doi.org/10.21438/rbgas.050915.

OLIVEIRA, A.D. de; CARVALHO, D.F. de; PEREIRA, J.B.A.; PEREIRA, V. da C. Crescimento e produtividade do pimentão em dois sistemas de cultivo. Revista Caatinga, v.28, p.78-89, 2015.

OLIVEIRA, N.L.C. de; PUIATTI, M.; SANTOS, R.H.S.; CECON, P.R.; BHERING, A. da S. Efeito da urina de vaca no estado nutricional da alface. Revista Ceres, v.57, p.506-515, 2010. DOI: https://doi.org/10.1590/s0034-737x2010000400011.

PAULUS, D.; VALMORBIDA, R.; SANTIN, A.; TOFFOLI, E.; PAULUS, E. Crescimento, produção e qualidade de frutos de pimenta (Capsicum annuum) em diferentes espaçamentos. Horticultura Brasileira, v.33, p.91-100, 2015. DOI: https://doi.org/10.1590/S0102-053620150000100001.

PIMENTA, S.; MENEZES, D.; NEDER, D.G.; MELO, R.A.; ARAUJO, A.L.R.; MARANHÃO, E.A.A. Adaptability and stability of pepper hybrids under conventional and organic production systems. Horticultura Brasileira, v.34, p.168-174, 2016. DOI: https://doi.org/10.1590/s0102-053620160000200004.

PONISIO, L.C.; M'GONIGLE, L.K.; MACE, K.C.; PALOMINO, J.; VALPINE, P. de; KREMEN, C. Diversification practices reduce organic to conventional yield gap. Proceedings of the Royal Society B: Biological Sciences, v.282, 20141396, 2015. DOI: https://doi.org/10.1098/rspb.2014.1396.

RIBES-MOYA, A.M.; RAIGÓN, M.D.; MORENO-PERIS, E.; FITA, A.; RODRÍGUEZ-BURRUEZO, A. Response to organic cultivation of heirloom Capsicum peppers: Variation in the level of bioactive compounds and effect of ripening. PLoS ONE, v.13, e0207888, 2018. DOI: https://doi.org/10.1371/journal. pone. 0207888 .

SANTOS, H.C.A.; LIMA JUNIOR, J.A. de; SILVA, A.L.P. da; CASTRO, G.L.S. de; GOMES, R.F. Yield of fertigated bell pepper under different soil water tensions and nitrogen fertilization. Revista Caatinga, v.33, p.172-183, 2020. DOI: https://doi.org/10.1590/1983-21252020v33n119rc. 
SCALZO, R.L.; CAMPANELLI, G.; PAOLO, D.; FIBIANI, M.; BIANCHI, G. Influence of organic cultivation and sampling year on quality indexes of sweet pepper during 3 years of production. European Food Research and Technology, v.246, p.1325-1339, 2020. DOI: https://doi.org/10.1007/s00217-020-03492-1.

SCOTT, A.J.; KNOTT, M. A cluster-analysis method for grouping means in the analysis of variance. Biometrics, v.30, p.507-512, 1974. DOI: https://doi.org/10.2307/2529204.

SHAHBANDEH, M. Global production of vegetables in 2019, by type. 2021. Available at: <https:/www.statista.com/ statistics/264065/global-production-of-vegetables-by-type/>. Accessed on: June 252021.
SILVA, A.R. da; CECON, P.R.; RÊGO, E.R. do; NASCIMENTO, M. Avaliação do coeficiente de variação experimental para caracteres de frutos de pimenteiras. Revista Ceres, v.58, p.168-171, 2011. DOI: https://doi.org/10.1590/s0034-737x2011000200006.

WORTHINGTON, V. Nutritional quality of organic versus conventional fruits, vegetables, and grains. Journal of Alternative and Complementary Medicine, v.7, p.161-173, 2001. DOI: https://doi.org/10.1089/107555301750164244.

ZAYED, M.S.; HASSANEIN, M.K.K.; ESA, N.H.; ABDALLAH, M.M.F. Productivity of pepper crop (Capsicum annuum L.) as affected by organic fertilizer, soil solarization, and endomycorrhizae. Annals of Agricultural Sciences, v.58, p.131137, 2013. DOI: https://doi.org/10.1016/j.aoas.2013.07.011. 